This is the accepted version of the article accepted for publication in South Asian History and Culture published online by Taylor \& Francis on 23 Aug 2016, available at: http://dx.doi.org/10.1080/19472498.2016.1223720

Accepted version downloaded from SOAS Research Online: http://eprints.soas.ac.uk/22864/

Marriage, Duty and Civilization: Keshab Chandra Sen and the Cuch Bihar Controversy in Metropolitan and Colonial Context

\author{
John Stevens ${ }^{1}$ \\ Department of the Languages and Cultures of South Asia, SOAS, University of London, \\ London, UK
}

The marriage in 1878 of Suniti Devi, the thirteen-year-old daughter of the Bengali Brahmo religious and social reformer Keshab Chandra Sen, to the Maharajah of Cuch Bihar constituted one of the most controversial matrimonial events in late colonial India. The marriage controversy was significant not only in terms of its effect on religious and social reform organizations in Bengal, but also in terms of the ways in which it served to challenge British attitudes towards the proper regulation of female sexuality in the empire. The British press took considerable interest in the marriage, celebrating it as an instance of the continued ability of the empire to spread civilization to India. However, this celebratory account served to occlude deeper contradictions. The contradictory character of the marriage fractured Keshab's relationship with the English Unitarians, Nonconformists and reformers who had long acted as his champions, and led to the demise of Keshabite Brahmoism as a force for national transformation in India. Through an exploration of responses to the marriage in both Bengal and Britain, this article demonstrates that varied and mutable conceptions of what constituted a male 'civilized subject' were intertwined deeply with discourses surrounding the regulation of female sexuality in both metropole and colony.

Keywords: Bengal; British imperialism; gender; marriage; Brahmoism.

\title{
Introduction
}

On 6 March 1878, Suniti Devi, the thirteen-year-old daughter of the Bengali social and religious reformer Keshab Chandra Sen (1838-1884), was married to Nripendra Narayan, the fifteen-year-old Maharajah of the north-eastern state of Cuch Bihar. The marriage created a storm of controversy in India and in Britain, as both parties were below the legal age of marriage as defined by the Brahmo Marriage Act of 1872, a piece of legislation which Keshab Chandra Sen himself had fought hard to make law. The marriage led directly to a major schism within the Brahmo Samaj of

\footnotetext{
${ }^{1}$ Email: js98@soas.ac.uk
} 
This is the accepted version of the article accepted for publication in South Asian History and Culture published online by Taylor \& Francis on 23 Aug 2016, available at: http://dx.doi.org/10.1080/19472498.2016.1223720

Accepted version downloaded from SOAS Research Online: http://eprints.soas.ac.uk/22864/

India, an organization which has been recognized by scholars as occupying a central position in the social, cultural and religious history of nineteenth-century Bengal. ${ }^{1}$ It resulted in a drastic decrease in the membership of the Brahmo Samaj of India, ruined Keshab's reputation amongst his closest reformist allies in Britain, and caused Keshab considerable public and personal distress. Rochona Majumdar has recently described the marriage as 'undisputedly among the most controversial matrimonial events that took place in late colonial India'. ${ }^{2}$

This article aims to offer a fresh perspective on the Cuch Bihar controversy, by analysing the discourses which shaped responses to the marriage in both Bengal and Britain. The Cuch Bihar marriage controversy was significant not only in terms of its effect on religious and social reform organizations in Bengal, but also in terms of the ways in which it served to challenge British attitudes towards the proper regulation of female sexuality in the empire. Responses to the marriage in Britain indicate that discourses concerned with female 'improvement' in imperial sites interacted in a complex manner with discourses surrounding issues of civilization, duty and imperial governance; this complex interaction could result, in certain circumstances, in Britons deciding to champion rather than to condemn 'child marriage'. Reponses to the marriage on the part of English Unitarians - who, in spite of their previous support for Keshab, reacted with unanimous condemnation - demonstrate the ways in which issues of marriage, sexuality, civilization and duty could set limits to the boundaries of inter-cultural dialogue, and fracture the inclusionary rhetoric of religious universalism. By placing Britain and Bengal within a single analytic frame, this article seeks to explore both the metropolitan and the colonial dimensions of the Cuch Bihar controversy.

As this article is concerned chiefly with the ways in which the Cuch Bihar marriage was constructed discursively between metropole and colony, the Anglophone press in Bengal and Britain constitutes a key source. Since the 1860s, Keshab had published Brahmo newspapers in both English and Bengali; following the Cuch Bihar controversy, his detractors within the Brahmo Samaj similarly established both English and Bengali-language mouthpieces. Articles from the Anglophone newspapers, particularly Brahmo Public Opinion and the Indian Mirror, were reprinted regularly in Unitarian and nonconformist Christian journals in England, and also, in 1878, in the national press. ${ }^{3}$ As Antoinette Burton has argued, Victorian domestic ideology was 'staged neither in Britain nor India alone but in the transnational communities of colonial culture that imperial social formations generated, of which the press was a crucial discursive technology'. ${ }^{4}$ In the case of the present article, the 'transnational' community generating much of the material under consideration was no doubt small: an urban, literate, English-educated Brahmo elite; an Anglo-Indian press tied closely to missionary enterprises and the colonial government; and a religiously marginalized, if politically influential, community of Unitarians in England. Nevertheless, the issues raised by the Cuch Bihar controversy spoke to a much broader audience in Britain, as is evidenced by the extensive national and regional press coverage, and the marriage itself had a profound impact on the development of social and religious reform in Bengal. 
This is the accepted version of the article accepted for publication in South Asian History and Culture published online by Taylor \& Francis on 23 Aug 2016, available at: http://dx.doi.org/10.1080/19472498.2016.1223720

Accepted version downloaded from SOAS Research Online: http://eprints.soas.ac.uk/22864/

\section{The Background}

The controversy surrounding the Cuch Bihar marriage is well documented, and has been the subject of impassioned and lengthy debates conducted by Brahmos and scholars ever since it took place. ${ }^{5}$ While commentators have taken a variety of positions regarding the purpose and consequences of the marriage, all have agreed with the view of Keshab's closest disciple, P. C. Majumdar, that the Cuch Bihar marriage 'formed the great turning point of Keshub Chunder Sen's career'. ${ }^{6}$ As David Kopf has observed, scholarly accounts of the controversy have tended to 'treat the marriage as a disaster from every point of view'. ${ }^{7}$ In Kopf's opinion, while the marriage damaged Keshab's reputation and led to a decrease in membership of the Brahmo Samaj of India, it served to strengthen Keshab's position in a region hitherto out of his sphere of influence; this line is also taken by Theodore Koditschek, who contends that the marriage was a 'strategic concession designed to enhance...[Keshab's] influence in India's more backward, less westernized, native states' ${ }^{8}$ In her study of marriage and modernity in colonial Bengal, Majumdar treats the Cuch Bihar marriage as an instance of a recurrent tension between secularist marriage reform legislation and the resilience of ritual observances in Hindu weddings. ${ }^{9}$ Keshab's Brahmo contemporaries, for the most part, regarded the Cuch Bihar marriage as a fundamental betrayal of Brahmo values and an instance of hypocrisy on the part of Keshab. The fact that Keshab has been relatively neglected in Bengali historiography seems to stem, in part, from the irrevocable damage the marriage controversy did to his reputation. ${ }^{10}$

At the time of the announcement of the marriage in September 1877, Keshab was one of the most prominent, powerful and controversial figures in Bengal. His distinctive approach to religious reform, fusing theistic Brahmo rationalism with popular forms of the Vaishnava and bhakti traditions, had found mass appeal through a series of missionary tours in the 1860s and 1870s; his activities in the field of social reform had expanded through the establishment of the Indian Reform Association, with its considerable network of schools, publications and charitable institutions. ${ }^{11}$ Keshab's reputation amongst government officials, social reformers and Christian activists in Britain was also considerable. His visit to England in 1870 transformed him into something of a celebrity: he lectured to a combined audience of over forty thousand people in the course of his stay, and his activities were reported in over fifty contemporary British newspapers and journals. ${ }^{12}$ The English Unitarians - who had been in contact with Brahmos in Calcutta since the 1820s, and shared their commitment to universal theism, social reform and rational religion - became particularly enamoured of him, regarding him as a 'prophet' of world-historical significance, whose visit to Britain constituted 'a landmark in our religious history'. ${ }^{13}$ Unitarian journals continued to report on Keshab's activities with great interest throughout the 1870 s and 1880s, and devoted considerable space to the events in Cuch Bihar. ${ }^{14}$

The initial impetus for the marriage was provided by the British government, who first approached Keshab with their proposal in August 1877. The British were 
This is the accepted version of the article accepted for publication in South Asian History and Culture published online by Taylor \& Francis on 23 Aug 2016, available at: http://dx.doi.org/10.1080/19472498.2016.1223720

Accepted version downloaded from SOAS Research Online: http://eprints.soas.ac.uk/22864/

attempting to strengthen their influence in Cuch Bihar, a princely state which had been subject to British suzerainty since the late eighteenth century, and had fallen under government control since the Maharajah had acceded to the throne at the age of ten months. As the work of Barbara Ramusack and others has shown, while the British had eschewed the annexation of princely states, interference in their internal politics was commonplace, ranging from the deposition of rulers, to advice about policies and appointments, to more subtle forms of social engineering. ${ }^{15}$ At the behest of the colonial government, the Maharajah had been educated by an English tutor and was to finish his education in England. His marriage to the daughter of a loyal subject of British rule, with close ties to the administration, would secure British influence in a strategically important region, which was at risk from Bhutanese incursions. ${ }^{16}$

Once the marriage had been agreed, the royal household of Cuch Bihar was quick to stipulate that the ceremony should be conducted in accordance with their preferred rites of Hindu 'orthodoxy', as opposed to Brahmo practice. A Hindu marriage was the only condition on which the matriarchs of the family would agree to the government's plans to send the Maharajah to England. As Angma Dey Jhala has demonstrated, royal marriages in the later nineteenth century brokered by the colonial government often resulted in officials becoming 'engaged in a political tug-owar of compromise with the matriarchs of the zenana'. ${ }^{17}$ Suniti Devi's own recollections of the marriage bear witness to the intense pressure under which Keshab was placed by the British negotiators, who frequently made assurances on behalf of the Cuch Bihar household which were not honoured. ${ }^{18}$ Keshab submitted numerous conditions in an attempt to secure the conformity of the marriage rites as far as possible to Brahmo practices, but during the event these conditions were not met, and the Brahmo newspaper the Sunday Indian Mirror was forced to admit that idols had been present at the marriage and that the hom ceremony had been performed in defiance of Keshab's strictures. ${ }^{19}$ The official Administration Report of the Cuch Bihar State and the Report on the Administration of Bengal, 1877-78, both stated that, despite some concessions to Keshab's party, the marriage had been 'recognized by the Hindus as orthodox' ${ }^{20}$

\section{The British Press}

It is significant that the event which created the greatest controversy in Keshab's entire career was one which revolved around the question of the proper regulation of his daughter's sexuality. The treatment of women had long functioned as a yardstick by which to judge the civilizational status of peoples - a striking example is the way in which the violent treatment of women and the break up of domestic order in the West Indies became central themes in debates concerning the abolition of slavery. ${ }^{21}$ Incidences of practices perceived to be particularly cruel towards women for example, the practice of foot-binding in China, of veiling and clitoridectomy in the Arab world and North Africa, and, in British India, the practice of sati - came to function as emblematic of the general 'barbarity' of peoples in a variety of colonial contexts. ${ }^{22}$ The reputation of Ram Mohan Roy amongst reformers in Britain (especially posthumously) was built in large part on his involvement with campaigns against sati; much of the British reformist enthusiasm for Keshab stemmed from his stance towards 
This is the accepted version of the article accepted for publication in South Asian History and Culture published online by Taylor \& Francis on 23 Aug 2016, available at: http://dx.doi.org/10.1080/19472498.2016.1223720

Accepted version downloaded from SOAS Research Online: http://eprints.soas.ac.uk/22864/

polygamy, child marriage and female education, and he himself regarded the Marriage Act of 1872 as his greatest achievement. ${ }^{23}$

Indeed, Keshab had attempted to garner support for a Marriage Bill during his visit to England in 1870, and the progress of his campaign was watched closely by a variety of British newspapers in Britain and India. When the 1872 Marriage Bill was proposed, the Anglo-Indian press in Calcutta, the missionary presses and the press in England uniformly declared themselves in favour it, as it would include in its provisions the prohibition of bigamy and polygamy, sanction inter-caste and widow marriages and prohibit 'child marriage' through the setting of a minimum marriageable age of fourteen and eighteen for females and males, respectively. The Times declared the Bill to be one of the government's 'cleverest hits in law-making' and 'one of the most important Bills ever framed with relation to India'. ${ }^{24}$ The importance of the Bill, according to The Times, lay in its reformation of a marriage system which, in India, constituted 'the pivot round which revolves the entire, gigantic, social system' ${ }^{25}$ The Pall Mall Gazette also advocated strongly in favour of the Bill, chiefly on the grounds that it would abolish 'the curse and disgrace of Hinduism' - 'infant marriages', and that the desire for 'religious reform' and 'purer morality' that motivated the marriage reform agitation were 'all the fruit and creation of British influence upon India'. ${ }^{26}$ Reports on the Marriage Act in the British press placed Keshab firmly at the centre of progressive liberal social reform in India in the imagination of the English public, and he was widely championed as an advocate of female improvement in India and a loyal British subject. $^{27}$

In this context, the fact that the Cuch Bihar marriage created so little opposition in the mainstream British press, even though it directly contravened the provisions of the 1872 Act, is worth exploring. The British press, when it devoted any space to the Cuch Bihar marriage, tended to react favourably, accepting, for the most part, the line taken by the government - that the marriage would secure British rule through an enlightened, English-educated Maharajah guided by rational and theistic principles. Reports tended to sideline (or frequently ignore) the fact that the marriage was underage according to the 1872 Act and had been recognized as 'orthodox'.

From the perspective of the British government, it was crucial that the marriage should take place according to conventions that were recognizably 'orthodox'. Assurances of orthodoxy were required in order to secure the consent of the royal household in Cuch Bihar; also, as the 1872 Act did not apply outside British India, a Brahmo marriage in Cuch Bihar would not have had legal validity. ${ }^{28}$ Furthermore, an orthodox marriage would appear to align with post-1857 official policy towards India in general. Following the events of 1857-8, Queen Victoria proclaimed publicly a policy of non-intervention in religious and social practices. Efforts to ameliorate social and moral conditions would now operate through the spread of education, encouraged through the wider availability of government grants to schools organized by Indian communities.

However, as a growing body of scholarship is demonstrating, social and religious intervention on the part of the colonial government did, in fact, persist post- 
This is the accepted version of the article accepted for publication in South Asian History and Culture published online by Taylor \& Francis on 23 Aug 2016, available at: http://dx.doi.org/10.1080/19472498.2016.1223720

Accepted version downloaded from SOAS Research Online: http://eprints.soas.ac.uk/22864/

1857, particularly in the area of marriage. ${ }^{29}$ As Rachel Sturman writes, 'the customs of marriage formed the grounds for a highly politicized fashioning of intimate life, linked at once to the material and symbolic reproduction of society and to questions of colonial governance'. ${ }^{30}$ By arranging an 'orthodox' Hindu marriage between a native prince and the daughter of a well-known, English-educated social reformer, the government could further British interests through dynastic match-making while appearing to adhere to a policy of non-intervention in matters of religious and social practice. Their claim that the marriage would promote the moral uplift of Indians by placing them in the care of an 'emancipated' ruler served to occlude the fact that they were engineering a marriage that contravened the government's own law of 1872 concerning legal marriageable age.

In general, the Anglophone press accepted this occlusion. While the Pall Mall Gazette expressed opposition to the marriage on the grounds that it was underage, and claimed that the Maharajah was likely to 'indulge in a plurality of wives hereafter', the view of The Examiner, which stressed the value of the opportunity presented to conduct an 'experiment of a Hindu ruler emancipated from the narrow superstitions of Hinduism', was more commonly taken. ${ }^{31}$ The Bristol Mercury, which devoted sustained coverage to Keshab during his visit to England in 1870, frequently citing him as a champion of the abolition of early marriage, declared that the government were 'worthy of all honour' and that the marriage would 'mark an epoch in the social history of India'. ${ }^{32}$ The age of the marrying parties was bypassed altogether, suggesting that, in this instance, the extension of British rule and the wider social good that would result was of greater import than a single early marriage. Notices of a telegram expressing Queen Victoria's congratulations to Keshab on the occasion of the marriage were widely circulated. ${ }^{33}$

The bride herself was notable by her absence from reports on the marriage, which focused instead on the involvement of eminent members of government, the favourable response of the Queen, and the good characters of the Maharajah and Keshab. The Bristol Mercury's announcement of the marriage reads as if the only two parties involved in the 'alliance' - 'proposed' and 'sanctioned' by the government - are Keshab and Prince Nripendra Narayan, both of whom can be counted on because of their good characters: 'He [the Maharajah] is an eminently amiable and teachable person, and it is fairly to be anticipated that his alliance with a man like Keshub Chunder Sen will tend immensely to the enlightenment and moral improvement of his country'. ${ }^{34}$ Any anxiety concerning the age of the marrying parties is alleviated - or, indeed, eclipsed - by the knowledge that Keshab is a civilized man of reputation, and that the young Maharajah is also a subject who is, or can become, civilized and respectable. Representations of Keshab circulating widely during his visit in 1870, which portrayed him as embodying a very 'English' form of 'manliness', clearly had left a lasting impression. ${ }^{35}$ What was not noted was that Keshab's 'manly' image in 1870 had rested in large part upon admiration for his 'enlightened' principles regarding women and Hindu 'orthodoxy', principles which were now compromised by the very same marriage the image was being used to justify. 
This is the accepted version of the article accepted for publication in South Asian History and Culture published online by Taylor \& Francis on 23 Aug 2016, available at: http://dx.doi.org/10.1080/19472498.2016.1223720

Accepted version downloaded from SOAS Research Online: http://eprints.soas.ac.uk/22864/

The importance of Keshab's reputation as a 'civilized' subject in gaining support for the marriage in the British press is made apparent further when the response to Cuch Bihar is considered alongside the sensational and highly-publicized scandals concerning early marriage that were to occupy the attention of the British press in the 1880s. Of these scandals, the case to generate the greatest degree of public interest and disapproval was the trial of Rukhmabai, which has been viewed by historians of Indian culture and society as one of the precursors to the Age of Consent Act of 1891 legislation which raised the age of consent for girls (including married girls) in India from ten to twelve. ${ }^{36}$ In 1884, Dadaji Bhikaji petitioned the Bombay High Court to direct that his wife Rukhmabai, who had married him as a child but had lived apart from him for over a decade, take up residence with him. The case was initially dismissed in 1885, but was later taken up again, culminating in 1887 when the courts ruled in favour of Dadaji, ordering Rukhmabai to move into his house or face six months imprisonment. ${ }^{37}$ The case caused a storm of controversy in India and in Britain, partly because the Matrimonial Causes Act had removed such penal provisions for English spouses in $1884 .^{38}$

Antoinette Burton, in her persuasive study of the Rukhmabai trial, argues that the late Victorian press 'made public' the body of an Indian woman as evidence of the necessity of British imperial rule at the same time that the Indian National Congress emerged as an expression of Indian political will in the metropolitan public eye. Burton contends that 'Implicit in this public display of the Hindu child bride was the argument that by virtue of their incapacity to protect - or manage - a recalcitrant wife, Indian men were as yet unfit for self-government'. ${ }^{39}$ Dadaji became subject to intense personal attacks in the British press, being characterized variously as 'vulgar', 'idle' and an 'ignorant and degraded peasant', despite his protestations that he was, in fact, a man of considerable property and education. ${ }^{40}$ If Rukhmabai came to function as emblematic of the oppressed condition of women in India in general, then Dadaji symbolized the ineffective and uncivilized nature of Indian men. In contrast, Keshab's image as respectable, educated and pious - a model 'civilized subject' - allowed the early marriage in which he had participated to function as symbolic of the possibility of the moral uplift of Indians, as opposed to emblematic of the limits of their transformative capacity. While child marriages were commonly understood at this time to contribute to the enervation and degradation of the Indian 'race' (and, by extension, the strength of the British empire), the Cuch Bihar marriage - understood as an 'alliance' between two respectable men, brokered by the government - could signify the possibilities of Indian amelioration as opposed to degradation.

While the memory of the respectable image Keshab created in 1870 was no doubt important in garnering the support of most of the British press for the Cuch Bihar marriage, it would be wrong to suggest that the images of respectable Keshab and 'vulgar' Dadaji were all that differentiated the two cases. The political and dynastic character of the Cuch Bihar marriage was, of course, a crucial factor in garnering public support, particularly considering that royal marriages often involved a degree of religious and cultural compromise in the interests of building alliances. Furthermore, the degree of public sympathy generated for Rukhmabai was due also to the fact that early marriage gained much greater recognition as a 'problem' worthy of British public 
This is the accepted version of the article accepted for publication in South Asian History and Culture published online by Taylor \& Francis on 23 Aug 2016, available at: http://dx.doi.org/10.1080/19472498.2016.1223720

Accepted version downloaded from SOAS Research Online: http://eprints.soas.ac.uk/22864/

interest in the 1880s than the 1870s. This was due to the coincidence of the Rukhmabai trial with a number of metropolitan cases which generated a moral panic concerning the regulation of female sexuality - the "Maiden Tribute of Modern Babylon" series concerning child prostitution in Britain published in the Pall Mall Gazette in 1885, the highly-publicized divorce proceedings of Sir Charles Dilke's alleged mistress, the repeal of the Contagious Diseases Acts in 1886 following the successful campaign led by Josephine Butler, and the implementation of the Criminal Law Amendment Act of 1885, which raised the age of consent for females in Britain from thirteen to sixteen. ${ }^{41}$ As Philippa Levine has demonstrated, imperial concerns contributed to anxiety about prostitution and venereal disease in many of these cases, due to the high incidence of venereal disease amongst soldiers in the empire. ${ }^{42}$

\section{Unitarian Responses}

While it would take the confluence of these metropolitan cases with the sensational Rukhmabai trial to make early marriage in India a subject of national public interest in Britain, child marriage had long been a concern of the reformist, Nonconformist and Unitarian circles with whom Keshab was in contact. For them, the Cuch Bihar marriage was nothing less than a sensation and an outrage. British social reformers had long regarded early marriage as a source of cultural stagnation in India and thus as an appropriate site of imperial intervention. ${ }^{43}$ It was Mary Carpenter who was responsible largely for generating interest in the issue amongst Victorian feminists from the late 1860s onwards with the publication of her hugely successful Six Months in India, which often focused on the 'degraded' condition of Indian women, articulated the Orientalist equation between 'heathen' religion and early marriage, and numbered amongst the consequences of early marriage a lack of opportunities for education and an inability to provide adequate maternal care for children. ${ }^{44}$ As Burton has argued, Carpenter's 'determination to improve Indian women's status was bound up with a desire to manage the bodies of Indian girls by diverting them from immediate marriage into professional occupations - a route toward improvement and "uplift" that brought them, from the 1870 s onward, under the discipline of professional, Western femalesupervised teacher training and that had as its ultimate goal the preservation of Indian women's procreative capacities inside the ideal of adult companionate marriage' ${ }^{45}$ For Carpenter, and for many others within the Nonconformist, Unitarian and reformist circles who followed Keshab's activities, the issue of early marriage thus brought together a number of key concerns: the 'problem' of women in India, the deplorable effects of Hinduism, the health of the Indian 'race' and the necessity for Western intervention.

Carpenter died the year before the Cuch Bihar marriage, but it seems safe to assume that her views on the event would have aligned broadly with those of Keshab's closest ally in Britain, Sophia Dobson Collet. Collet, more than any other figure, had been responsible for introducing Keshab to the British public before and during his visit to England, and had remained one of his most ardent champions throughout the 1870s. She was deeply shocked to hear of the 1878 marriage, and regarded it as a dreadful betrayal by a close friend. Throughout the $1870 \mathrm{~s}$, Collet had tried to encourage equilibrium between the cultivation of the objective (that is, directed 
This is the accepted version of the article accepted for publication in South Asian History and Culture published online by Taylor \& Francis on 23 Aug 2016, available at: http://dx.doi.org/10.1080/19472498.2016.1223720

Accepted version downloaded from SOAS Research Online: http://eprints.soas.ac.uk/22864/

towards social reform) and subjective (that is, directed towards individual spiritual growth) aspects of religion in the Brahmo Samaj, but the events of 1878 proved to her that this attempt had failed. Her concern had arisen 'two or three years ago', when 'Mr. Sen's increasing absorption in religious meditation began to draw away his attention and sympathy from other departments of Brahmic life'. ${ }^{46}$ She pointed out that Majumdar, writing in 1877, had warned of the disastrous effect that would result if 'the valuable agencies of life, thought, and feeling imparted from the West...are suffered to grow feeble and inoperative....there is not much doubt that this result will follow, unless we combine the spirit of the East and the West in all our endeavours' ${ }^{47}$ In Collet's view, it was the spirit of the 'East' that had come to preponderate, and 'alas! the reactionary wave has carried away even the thinker who uttered the warning'. ${ }^{48}$

The decline of the Samaj's educational institutions and the discontinuance of the government grant-in-aid to the Brahmo Normal School in 1878 were evidence that 'the once energetic and enterprising 'Brahmo Somaj of India' gradually declined from its original position, both in theory and practice'. ${ }^{49}$ Collet castigated Keshab for his hypocrisy in sanctioning an early and 'heathen' marriage, and accused him of 'ignoring reality' in the course he took - this total ignoring of reality perhaps the final consequence of an increasingly inwardly-directed spiritual quest. ${ }^{50}$ Collet rejected the self-effacing arguments Keshab advanced in 1879 in his lecture "Am I an Inspired Prophet?", and described him in The Brahmo Year Book of 1879 as tending 'more and more towards the consolidation of a spiritual autocracy'. ${ }^{51}$ Collet would continue to oppose Keshab vociferously throughout the 1880s, regarding him as an autocrat, a blasphemer and, ultimately, a madman.

However, the shock of Keshab's defection from the Unitarian social gospel and apparent embrace of autocratic spiritual mysticism did not in any way shake Collet's belief in the bright future that lay ahead of the 'Brahmo Samaj' (by which she now meant the Sadharan Brahmo Samaj). The commitment of the Sadharan Brahmos to constitutional church government, liberal social reform and female education aligned directly with Collet's belief in a liberal Unitarian social gospel. Collet disassociated Keshab from the Brahmo movement as a whole, which, in her eyes, had never swerved from the path of progress: 'That the Brahmo Samaj was expanding and advancing, while Mr. Sen was standing still or going backward, has been evident to me for the last two or three years'. ${ }^{52}$ Collet lamented that Keshab had suffered the decline which often befalls 'once-brilliant public men', and stated that 'I mourn his retrogression from his former self'. ${ }^{53}$ The 'Keshab' of 1870 - 'his former self' - was the Keshab that Collet regarded as the 'real' Keshab; it was this 'Keshab' that she had attempted to protect from the dangers of asceticism and spiritual intoxication. But the 'former self' had proved too fragile to walk the delicate line between the spiritual and the material aspects of religion.

The Inquirer was less hasty in its condemnation of Keshab than Collet, preferring to reserve judgement on Keshab's actions until he produced a defence of them. When a defence from the Indian Mirror (albeit not authored by Keshab) was received in May 1878, which justified the marriage primarily on the grounds that it was the product of Divine command or adesh, The Inquirer declared itself immediately to 
This is the accepted version of the article accepted for publication in South Asian History and Culture published online by Taylor \& Francis on 23 Aug 2016, available at: http://dx.doi.org/10.1080/19472498.2016.1223720

Accepted version downloaded from SOAS Research Online: http://eprints.soas.ac.uk/22864/

be 'entirely converted' to the views of Collet. ${ }^{54}$ The editorial focused on the defence of the marriage on irrational grounds as opposed to the marriage itself as the greatest source of outrage, and suggested that Keshab's invocation of adesh was insincere: 'Mr. Sen is much too able a man to deceive himself with this sort of cant. When a person of unimpeachable character does something that is particularly indefensible....[they] in unctuous tones assert that "all is ordered by Providence."...we had thought that Mr. Sen occupied an infinitely higher plane'.$^{55}$ It was Keshab's justification of the marriage on the grounds of adesh which also generated the greatest degree of consternation amongst other elements of the religious press in Britain. Echoing comments made by the conservative Anglican publication The Record, The Free Church of Scotland Monthly Record proclaimed that Brahmoism had been claiming for itself a higher authority than the Gospel, and had thus become an 'inflated bladder' that would 'burst by-and-by'. ${ }^{56}$ The 'glory of having a royal son-in-law' had led Keshab to 'act cruelly towards his daughter' and to 'violate both the law of society and his own conscience'. ${ }^{57}$ There was no doubt that the Samaj's influence was 'destroyed'. ${ }^{58}$

\section{Responses in Calcutta}

In the Calcutta press, the marriage created a storm of controversy. Child marriage, practiced by the higher castes in India since the Christian era, had become widespread in the nineteenth century, and its reform became the subject of debate amongst Indian reformers as they responded to missionary criticisms of the custom in the early nineteenth century. Many of these debates concerned the question of whether evidence of its sanction in sacred law was outweighed by descriptions of adult marriages in the Vedas. ${ }^{59}$ Attempts to reform legislation in order to abolish the custom began in the 1850s with Vidyasagar, whose efforts led the government to include an age of consent provision in the Penal Code of 1860, making sexual intercourse with a girl under ten qualify as rape. ${ }^{60}$ The custom of early marriage had, by the $1870 \mathrm{~s}$, become a characteristic concern amongst a variety of nationalists, who, as Burton has argued, 'critiqued the Hindu marriage system...even as they placed it at the heart of their socio-cultural struggle against Western values and influences' ${ }^{61}$ Early marriage was thus an issue of intense interest amongst a variety of reformers and nationalists in the 1870s, and arguably no one had done more to stimulate this interest than Keshab himself, with his successful (if limited) reform of the custom in 1872.

As Keshab's reputation in Calcutta was inextricably linked with his efforts to improve the condition of women and to reform marriage customs, it is unsurprising that the Cuch Bihar marriage caused a sensation, and a certain degree of disbelief. According to the vast majority of commentators, Keshab had placed himself in a position of patent and indefensible hypocrisy. According to Collet, the Indian Daily News, Indian Church Gazette, Indian Tribune, the East, the Dacca Prakash and the Subodha Patrika all formed part of the 'almost unanimous consensus of opinion against Mr. Sen, both as to the marriage itself, and the plea of Adesh...set up in its defence'. ${ }^{62}$ The Friend of India initially withheld judgement, but later stated vigorously its opposition to the fact that the marriage had been underage, and that Keshab had defended it on the grounds of adesh: 'The Brahmo leader...appears to have reached that unfortunate stage in the history of some prophets, when they receive special 
This is the accepted version of the article accepted for publication in South Asian History and Culture published online by Taylor \& Francis on 23 Aug 2016, available at: http://dx.doi.org/10.1080/19472498.2016.1223720

Accepted version downloaded from SOAS Research Online: http://eprints.soas.ac.uk/22864/

revelations to sanction their own irregularities; and the marriage itself affords less ground for questioning his fitness to remain at the head of the community than the very dangerous doctrine he has advanced in his defence' ${ }^{63}$

Opposition to the marriage was led by members of the Samadarshi faction, who had been opposed throughout the 1870s to Keshab's increasingly authoritarian style of leadership, his doctrine of adesh and his reverence for 'Great Men'. They broke formally with the Brahmo Samaj of India as a consequence of the marriage, and instituted the Sadharan Brahmo Samaj on 15 May 1878. The Samalachak and Brahmo Public Opinion, both established in early 1878, published a stream of articles condemning the marriage. Keshab was criticized for sanctioning a marriage that was underage and idolatrous, and for defending it on the basis of adesh - a defence which confirmed his pretensions to spiritual autocracy. ${ }^{64}$ Brahmo Public Opinion claimed that God could not have countenanced the marriage, as it was idolatrous, and that Keshab's claim of adesh was thus 'either deluded or deceitful'. ${ }^{65}$ While Brahmos accepted a doctrine of adesh which also recognized nishedh (the prohibition of certain forms of conduct), adesh without nishedh was a doctrine 'invented only very recently, to justify the conduct of Babu K. C. Sen'. ${ }^{66}$ This distinction between the two forms of the doctrine was drawn in a statement issued by the Sadharan Brahmo Samaj following a public meeting in May 1878: 'We consider it a blasphemy...to claim Divine inspiration for any act opposed to the dictates of reason, truth, and morality'. ${ }^{67}$ Inspiration without reason was contrary to moral law, and tended towards 'uncontrolled authority by a single individual'; when this individual was looked upon as 'a link between God and Man', the principles of theism were violated. ${ }^{68}$ The Sadharan Brahmo Samaj was set up on a constitutional basis and emphasized the need for liberal social reform and rational religion.

In sanctioning the Cuch Bihar marriage, Keshab effectively contradicted many of his strongest beliefs as expressed throughout the 1860s and 1870s, contravened his greatest legislative achievement as a reformer (the $1872 \mathrm{Act}$ ), and betrayed - in the eyes of many - the fundamental principles of progressive Brahmoism. His reputation amongst the vast majority of like-minded religious and social reformers in Britain was ruined, and the membership of the Brahmo Samaj of India was reduced considerably. Reportedly, fifty provincial Samajes sided with the Sadharan Brahmo Samaj in opposition to his actions. ${ }^{69}$ The schism was bitter and the actions of both parties including the publication of numerous scurrilous pamphlets criticizing the moral character of Brahmo leaders on both sides, anonymous letters written to the government accusing Keshab of misappropriating the funds of the Cuch Bihar treasury, and a physical confrontation at the Brahmo Mandir which ended with the police being called - made the usually respectable and earnest Brahmos the objects of considerable public derision. ${ }^{70}$ As Majumdar recalls, the controversy caused Keshab to fall into a deep depression: he refused to answer the calls or read the protests of those demanding an explanation for his actions; he became increasingly paranoid and 'talked wildly of the dangers to his Church, the bitter animosities and ill-treatment which dogged him'. $^{71}$ In Meredith Borthwick's opinion, Keshab suffered a 'nervous breakdown'. ${ }^{72}$ 
This is the accepted version of the article accepted for publication in South Asian History and Culture published online by Taylor \& Francis on 23 Aug 2016, available at: http://dx.doi.org/10.1080/19472498.2016.1223720

Accepted version downloaded from SOAS Research Online: http://eprints.soas.ac.uk/22864/

\section{The Public and the Sacred}

Why did Keshab agree to a marriage that caused him so much public and personal distress? In her study of women and law in colonial India, Janaki Nair suggests that Keshab's agreement to the marriage can be seen as an instance of 'the gap between public (political) and private positions of reformers such as Roy, Sen or Ranade, [which] was one of the persistent ironies of the process of social reform, and was an expression of the contradictions inherent in the colonial social order'. ${ }^{73}$ According to this reading, Keshab agreed to the marriage because his private attitude towards child marriage was distinctly less 'reformist' than the views he expressed publicly, and he chose, in this instance, to follow his private as opposed to his public convictions. While there can be no doubt that Keshab's private attitudes towards women were in a process of transition in the 1870s (his public dispute with British educationalist Annette Ackroyd stands as one example), the evidence suggests that he did not eschew his public duties in favour of his private beliefs, but, in fact, did quite the opposite. ${ }^{74}$

It may be argued that Keshab's willingness to agree to the marriage stemmed from the intense pressure he was placed under by the British government to agree, and from his unswerving faith in the Providential nature of British rule in India. As Mozoomdar recalls, 'He fervently believed...that the representatives of the British Government could never deceive him' ${ }^{75}$ Keshab wrote later to Max Müller that his agreement to the marriage had stemmed from a combination of his conviction that the marriage was Providential, and his duty to place public good before individual interests: 'I saw the finger of God in all the arrangements, trials and struggles in connection with the marriage....A whole kingdom was to be reformed, and all my individual interests were absorbed in the vastness of God's saving economy, or in what people would call public good'. ${ }^{76}$ In a private letter to Frances Power Cobbe of April 29 1878, Keshab acknowledged that, in deciding whether to sanction the marriage, he was forced to choose between his 'private' and 'public' selves:

I never sought a Raja. I never coveted filthy lucre. As a private man I should not probably have acted as I have done. But I was acting all along as a public man...[The proposal would] help forward the good work so gloriously begun in that State by our benevolent rulers in the interests of millions of the subject population....You have justly said that a grave responsibility would have rested upon me if I had refused the overtures of the Government....I have acted as a public man under the imperative call of a public duty. All other considerations were subordinated to this sacred duty. All other considerations were subordinated to this sacred call, this Divine injunction. ${ }^{77}$

This defence draws upon the familiar tropes amongst religious and social reformers of the period of personal sacrifice in the name of duty. Keshab had sacrificed his private beliefs in order to further the pubic good. What is striking is the elision of 
This is the accepted version of the article accepted for publication in South Asian History and Culture published online by Taylor \& Francis on 23 Aug 2016, available at: http://dx.doi.org/10.1080/19472498.2016.1223720

Accepted version downloaded from SOAS Research Online: http://eprints.soas.ac.uk/22864/

the 'public' and the 'sacred': as the British government was guided by Providence, so its requests become Divine injunctions. Nair may be right to suggest that the difference between public and private positions of Indian reformers expressed contradictions inherent in the colonial social order - as we have seen, in his domestic life, Keshab struggled to resolve his roles as a 'native gentleman' and an urban guru. However, in the Cuch Bihar case, it was Keshab's private position that remained the more 'reformist' (at least according to what 'reformist' meant for progressive Brahmos and Keshab's Nonconformist and Unitarian allies in Britain) and his public position (necessitated by his relationship to the colonial authorities) that appeared 'conservative'. Nair's formulation suggests that the opposite was usually the case.

Keshab's elision of the public and the sacred complicates accounts of Indian nationalism which regard nationalism as first forging a domestic, 'spiritual domain', before entering the realms of the political. ${ }^{78}$ For Keshab, the political was precisely the 'spiritual' - the unfolding of history, and the crucial role played in it by the Providentially-sanctioned British empire, constituted an expression of God's will. The great difficulty for Keshab was that his private beliefs (and his 'inner' spiritual development) and his public duties (to the external world) were both sacred. In the 1860 s and 1870s, Keshab's commitment and approach to the amelioration of women in India had been applauded by the government and at times directly furthered through legislation; the direct alignment between the reformist goals of the Brahmo Samaj of India and the desire of the British authorities and people had been confirmed, in Keshab's eyes, during his visit in 1870. By 1878, on the key principle of early marriage, the progressive Brahmo and British government positions were in direct opposition. Keshab had to conform to government requests as they had Divine sanction, but the requests contradicted the reformist and religious principles he held on the basis of rational enquiry. Keshab could not find a rational argument which would synthesize this opposition. Keshab was faced in 1878 with the starkest possible choice between his private and public lives, his position as an 'Indian' and as a 'man of the world', his reputation as an Indian reformer and a loyal British subject. ${ }^{79}$ In the end it was adesh rather than reason to which he turned in order to make the choice.

While it is not possible to know exactly how Keshab viewed his own relationship to adesh (a concept which he rendered in English variously as 'inspiration' and 'Divine command'), there can be no doubt that Keshab's tendency in his later years to justify his decisions on the basis of it was marked by a considerable degree of self-doubt. The extraordinary candour with which he wrote in his "devotional" column in the Sunday Indian Mirror of January 1878 indicates that he was, at the very least, deeply concerned that he was coming to believe that his own ideas were of a uniquely Divine origin, and that this belief was a delusion:

I have strangely got into the habit, $\mathrm{O}$ my God, of crediting Thee with all my ideas and plans. I, as Thy servant, ought to follow only Thy commandments, forsaking all that pleases me and adopting whatsoever is agreeable to Thee. But instead of doing this, I strive to follow my own plans and schemes and then ascribe to Thee their authorship. Having come so far in the path of religion, I feel it a humiliation to believe that I am carrying out my own wishes. I would fain believe that in all my doings I only follow Thy leading, and I feel glad when people give me credit for obeying Thy will and sacrificing my own. But as self-sacrifice is a hard thing, and I am carried away by my own ideas, feelings, and tastes, all that I can do is to make myself and others believe that everything I do is the Lord's doing, and that all 
This is the accepted version of the article accepted for publication in South Asian History and Culture published online by Taylor \& Francis on 23 Aug 2016, available at: http://dx.doi.org/10.1080/19472498.2016.1223720

Accepted version downloaded from SOAS Research Online: http://eprints.soas.ac.uk/22864/

my purposes are divine purposes. Thus errors and vices in my life become sacred in my estimation in the course of time with the imaginary imprimatur of Thy seal. Lord, deliver me from this delusion. ${ }^{80}$

While the demands of his public duty to bring reform to the state of Cuch Bihar in alliance with a Divinely-sanctioned British government had, according to Keshab, outweighed the necessity of conforming to his private beliefs concerning the rites of marriage, the marriage did not, in fact, lead Keshab to eschew the cultivation of the subjective side of religion and launch once more into a program of social reform. Rather, the opposite was the case. The marriage led to a significant decrease in the membership of the Brahmo Samaj of India. While the partisan nature of the accounts of the schism of 1878 makes it difficult to discern the exact extent of the opposition to Keshab's actions, there can be no doubt that a large proportion of educated middleclass members of the Brahmo Samaj of India deserted Keshab because of the marriage. Keshab's public reputation was severely damaged and his influence greatly reduced. This reduction in membership led the core of Keshab's Brahmo Samaj to assume increasingly the form of a close-knit community of devoted followers, with Keshab functioning as the central charismatic leader. ${ }^{81}$ Shortly before the marriage, Keshab had purchased Lily Cottage, a large mansion which he occupied in November 1877; in early 1878, a project was initiated to provide the Brahmo missionaries and their families with homes on the Cottage grounds; this neighbourhood was consecrated as Mangal Bari (Abode of Welfare) in January 1879. The missionaries were Keshab's most loyal adherents (with the exception of Bijoy Krishna Goswami, they all sided with him in 1878), and they formed the nucleus of adherents to the New Dispensation, an organization over which Keshab would assume an increasingly authoritarian control. $^{82}$

\section{Conclusion}

The Cuch Bihar marriage certainly formed a turning point in Keshab's life and career. While the marriage was supported, in general, in the British press, it marked the end of the English Unitarians' admiration for Keshab, and resulted in the decline of Keshabite Brahmoism as a force for national transformation in India. While Keshab initially defended the marriage on the grounds that it would engender an expansion of the Brahmo fold through the extension of Brahmo influence into Cuch Bihar, he later came to use the marriage as a justification for a necessary and Providentially-sanctioned contraction in his organization's membership. Writing in the Sunday Indian Mirror in 1880 , he proclaimed that the 'winnowing fan' of Cuch Bihar 'has done, and is doing, immense good to the Brahmo Somaj by removing the chaff from its membership'. ${ }^{83}$ The 'winnowing fan' of Cuch Bihar was invocated repeatedly by Keshab in his final years as a means of justifying his increasing focus on individual spiritual self-realization as opposed to social transformation.

In the British context, the fact that the Cuch Bihar marriage found widespread support within the mainstream secular press demonstrates that discourses which critiqued the 'superstitious' customs of 'Hindus', particularly in relation to the treatment of women, existed in persistent tension with broader notions concerning the duty of the British government to engender 'moral uplift' through collaboration with 'civilized' male subjects. The reform and regulation of female bodies and female 
This is the accepted version of the article accepted for publication in South Asian History and Culture published online by Taylor \& Francis on 23 Aug 2016, available at: http://dx.doi.org/10.1080/19472498.2016.1223720

Accepted version downloaded from SOAS Research Online: http://eprints.soas.ac.uk/22864/

sexualities may have been a recurrent concern of British imperialism, but what was deemed to constitute 'progressive reform' could vary considerably according to the specific political context. For the English Unitarians, the abolition of child-marriage on rational grounds formed a central tenet of their reformist social gospel with respect to India. Keshab's rejection of this principle took him outside the limits of the intercultural religious dialogue in which the Brahmos and Unitarians had engaged so enthusiastically throughout the nineteenth century. In trying to make sense of Keshab's decision, the English Unitarians fell back on conventional discourses concerning the dangerously irrational character of religions of the 'East', while simultaneously reframing their view of the history of Brahmoism in a way which allowed them to shift their hopes for its future away from Keshab and onto the more 'rational' men of the Sadharan Brahmo Samaj. The Cuch Bihar marriage controversy demonstrates that varied and mutable conceptions of what constituted a male 'civilized subject' were inextricably linked with discourses surrounding the regulation of female sexuality in both metropole and colony.

\section{Acknowledgements}

This work was supported by the Leverhulme Trust, under grant number ECF/2012-703.

\section{Notes}

1. For a comprehensive history of the Brahmo Samaj, see Kopf, The Brahmo Samaj. The broader historiography of the Bengal renaissance is discussed in Raychaudhuri, Europe Reconsidered, 345-362.

2. Majumdar, Marriage and Modernity, 168.

3. Keshab's closest ally in Britain, the Unitarian Sophia Dobson Collet, was a crucial figure in this process: she meticulously gathered and circulated Anglophone Brahmo publications, encouraged Brahmos and Unitarians to maintain public correspondence, and published her own annuals on Brahmoism.

4. Burton, "From Child Bride," 1145.

5. For a defence of Keshab's conduct, see Mozoomdar, The Life and Teachings; for the viewpoint of the Samadarshi party, see Sastri, History; for reprints of documentary evidence, see Sen, Biography of a New Faith.

6. Mozoomdar, The Life and Teachings, 321. 
This is the accepted version of the article accepted for publication in South Asian History and Culture published online by Taylor \& Francis on 23 Aug 2016, available at: http://dx.doi.org/10.1080/19472498.2016.1223720

7. Kopf, The Brahmo Samaj, 327.

8. Ibid., 327; Koditschek, Liberalism, 278.

9. Majumdar, Marriage and Modernity, 167-205.

10. Many partisan accounts of the Brahmo movement have been written. Sophia Dobson Collet's The Brahmo Year Book (1876-1883) was the chief source on Brahmo activities for British audiences, and demonstrates Collet's attempts to 'write Keshab out' of the 'true' history of Brahmoism following the Cuch Bihar controversy. Rabindranath Tagore, speaking to an audience of Unitarians in Britain in 1930, also presented a history of Hindu and Brahmo reform which carefully omitted any reference to Keshab. See Radice, "Tagore's The Religion of Man."

11. For a list of Brahmo Samajes across India in 1872, see Kopf, The Brahmo Samaj, 325-327. The establishment of a Brahmo Samaj typically involved the building of a mandir (community prayer hall and meeting place), a girls' and boys' school, possibly a college, a discussion society for youth, a charitable hospital, printing press, a night school for peasants and workers, and a ladies' society. From November 1870 , the cheap literature section published a weekly newspaper in Bengali - the Sulabh Samachar - which was designed to foster moral discipline, self-reliance and basic education. It sold 281,149 copies in its first fourteen months and remained relatively popular - in 1879 190,000 copies were sold. See Kopf, The Brahmo Samaj, 18.

18. Chatterjee provides a more conservative estimate - a peak circulation of 27,000 within the newspaper's first three months - but agrees that, in 1877, it was still the most widely-circulated Bengali-language newspaper. Chatterjee, The Nation, 44.

12. The two main sources on Keshab's visit to England are Writers Workshop, Keshub Chunder Sen and Collet, Keshub Chunder Sen's English Visit.

13. The Inquirer, July 2, 1870.

14. See in particular The Inquirer, 1870-1885.

15. Ramusack, The Indian Princes; Ernst and Pati, India's Princely States. 
This is the accepted version of the article accepted for publication in South Asian History and Culture published online by Taylor \& Francis on 23 Aug 2016, available at: http://dx.doi.org/10.1080/19472498.2016.1223720

Accepted version downloaded from SOAS Research Online: http://eprints.soas.ac.uk/22864/

16. For Nripendra Narayan's lineage and a discussion of Suniti Devi's life, see Moore, Maharanis, 52-71.

17. Jhala, Courtly Indian Women, 78.

18. Devee, Autobiography, 42-67. For a discussion of Suniti Devi's memoir - the first published by an Indian woman in English - see Moore, Maharanis, 52-71. For the symbolic and literal role of women in royal marriages, including Suniti Devi's, see Jhala, Courtly Indian Women. Another of Keshab's daughters, Sucharu Devi, married into a royal family in 1904, twenty years after Keshab's death. She had waited fourteen years to marry the Maharajah of Mayurbhanj, after initial negotiations fell apart due to Keshab's reputation for radicalism. See Writers Workshop, Sucharu Devi.

19. Sunday Indian Mirror, March 17, 1878.

20. Borthwick, Keshub Chunder Sen, 192. These reports appeared in the Sunday Indian Mirror, December 22, 1878. A copy of the first, signed by the Deputy Commissioner G. T. Dalton, in which it is stated that the marriage was a 'Hindu marriage' of 'perfect orthodoxy', can be found in Müller, Biographical Essays, 99101.

21. For the focus on the sexual violence of white planters towards the enslaved, see Paton, "Decency, Dependence," and Ferguson, The History of Mary Prince.

22. Janaki Nair argues that the foregrounding of the position of women in order to denigrate politically and economically subjugated cultures was a strategy which was followed by nearly all imperial powers in the nineteenth century. Nair, Women and Law, 51-52.

23 For the history of the 1872 Marriage Act, see Majumdar, Marriage and Modernity, 167-205.

24. The Times, February 5, 1872.

25. The Times, September 11, 1871.

26. Pall Mall Gazette November 4, 1871. The Times and Pall Mall Gazette were the principal sources of information on the Marriage Bill in the secular press in England, and their articles on the subject were reprinted widely (see, for example, 
This is the accepted version of the article accepted for publication in South Asian History and Culture published online by Taylor \& Francis on 23 Aug 2016, available at: http://dx.doi.org/10.1080/19472498.2016.1223720

Accepted version downloaded from SOAS Research Online: http://eprints.soas.ac.uk/22864/

Birmingham Daily Post, August 23, 1871; Leeds Mercury, August 22, 1871;

Glasgow Herald, February 8, 1872). In Calcutta, the Bill was supported by the Calcutta Review, The Friend of India, Pioneer, Englishman, Hindu Patriot and Indian Daily News.

27. Keshab's efforts on behalf of women were written of approvingly in the Englishwoman's Review, April 1, 1871; Frances Power Cobbe wrote in the Pall Mall Gazette, May 6, 1871, that Keshab was 'principally devoted...to the improvement of the condition of his countrywomen'. Keshab's letters to the Queen and his expressions of loyalty (for example, his sadness at the death of Lord Mayo) were widely reported (see, for example, The Graphic, March 23, 1872; Birmingham Daily Post, April 3, 1872). His reputation as a social reformer even led to a series of advertisements in which he appeared as an endorsee of a treatise concerning the rationale of hygiene. Manchester Times, April 29, 1871.

28. The legal point is made in Collet, The Brahmo Year Book (1878), 30.

29. Sturman, The Government; Sharafi, Law and Identity; Chatterjee, Gender, Slavery.

30. Sturman, The Government, 150.

31. Pall Mall Gazette, March 11, 1878; The Examiner, June 22, 1878.

32. Bristol Mercury, March 23, 1878.

33. See, for example, Aberdeen Weekly Journal, April 4, 1878; Hampshire Telegraph and Sussex Chronicle, April 6, 1878.

34. Bristol Mercury, March 23, 1878. This account was reprinted in a number of provincial newspapers - for example, The Blackburn Standard: Darwen Observer and North-East Lancashire Advertiser, March 23, 1878.

35. See, for example, Pall Mall Budget, April 23, 1870; The Saturday Review, June 4, 1870.

36. Burton, "From Child Bride," 1120. For the agitation leading to the Age of Consent Act, see also Forbes, "Women and Modernity" and Heimsath, "The Origin and Enactment."

37. The case is discussed in detail in Burton, "From Child Bride."

38. Ibid., 1120. 
This is the accepted version of the article accepted for publication in South Asian History and Culture published online by Taylor \& Francis on 23 Aug 2016, available at: http://dx.doi.org/10.1080/19472498.2016.1223720

39. Ibid., 1122.

40. The quotations are from articles in the provincial press quoted in Ibid., 1136. Burton argues that metropolitan representations of Dadaji also reduced him to a 'coolie-like status'.

41. For a discussion of the "Maiden Tribute" series and an analysis of late-Victorian anxieties concerning the regulation of sexuality, see Walkowitz, City of Dreadful Delight; for campaigns against the Contagious Diseases Acts, see Walkowitz, Prostitution and Victorian Society.

42. See Levine, "Venereal Disease, Prostitution," and Levine, Prostitution, Race and Politics.

43. Forbes, "Women and Modernity," 407.

44. Carpenter, Six Months in India. The principal themes of the text are discussed in Burton, "Fearful Bodies."

45. Burton, "Fearful Bodies," 549.

46. Collet, The Brahmo Year Book (1878), 78.

47. Majumdar writing in the Theistic Annual for 1877, quoted in Ibid., 79.

48. Ibid.

49. Ibid.

50. Ibid., 82 .

51. Ibid. (1879), 5.

52. Ibid. (1878), 83.

53. Ibid.

54. The Inquirer, May 18, 1878.

55. Ibid.

56. The Free Church of Scotland Monthly Record, September 2, 1878.

57. Ibid.

58. Ibid.

59. Forbes, "Women and Modernity," 408. For a discussion of child marriage in Hindu sacred texts, see Kapadia, Marriage and Family in India. 
This is the accepted version of the article accepted for publication in South Asian History and Culture published online by Taylor \& Francis on 23 Aug 2016, available at: http://dx.doi.org/10.1080/19472498.2016.1223720

Accepted version downloaded from SOAS Research Online: http://eprints.soas.ac.uk/22864/

60. Forbes, "Women and Modernity," 408. No age restrictions applied to marriage itself under this legislation, only consummation.

61. Burton, "From Child Bride," 1125.

62. Collet, The Brahmo Year Book (1878), 6.

63. The Friend of India, April 12, 1878.

64. For a summary of articles, letters and petitions of protest, see Collet, The Brahmo Year Book (1878), 9-77. Collet prints forty-four letters against the marriage, seven criticizing the protesters, and two approving of the marriage. However, she was strongly biased in favour of the Sadharan Brahmo Samaj.

65. Brahmo Public Opinion, June 6, 1878, reprinted in Ibid., 77.

66. Ibid., 77.

67. Ibid., 75.

68. Ibid., 75 .

69. This figure is claimed by Brahmo Public Opinion, March 21, 1878. See also Damen, Crisis and Religious Renewal, 184.

70. Mozoomdar, The Life and Teachings, 333-335.

71. Ibid., 339.

72. Borthwick, Keshub Chunder Sen, 197.

73. Nair, Women and Law, 72.

74. For the dispute with Ackroyd, see Scherer, "A Cross-Cultural Conflict."

75. Mozoomdar, The Life and Teachings, 329.

76. Keshab to Max Müller, May 2, 1881, reprinted in Müller, Biographical Essays, 114.

77. Keshab to Frances Power Cobbe, April 29, 1878, reprinted in Sen, Biography of a New Faith, p.192. Keshab's letter to Cobbe was the only 'public' (in that he intended it to be published for English audiences) defence he made of the marriage in the 1870s. The evidence does not provide any clear explanations as to why he refused to defend himself publicly in Calcutta or to write to any journals or newspapers himself in Britain, but chose instead to write only to an Englishwoman he had met briefly during his time in Britain. Keshab knew, perhaps, that Cobbe would be sympathetic - she wrote a defence of him in 
This is the accepted version of the article accepted for publication in South Asian History and Culture published online by Taylor \& Francis on 23 Aug 2016, available at: http://dx.doi.org/10.1080/19472498.2016.1223720

Accepted version downloaded from SOAS Research Online: http://eprints.soas.ac.uk/22864/

Christian Life, March, 1878, arguing that he had been forced to compromise his principles in the interest of the wider social good.

78. This view of nationalism is advanced in Chatterjee, The Nation.

79. Speaking on the day of his departure from Southampton on September 17, 1870, Keshab described himself as both 'an Indian' and 'a Man of the World'. Writers Workshop, Keshub Chunder Sen, 464.

80. Sunday Indian Mirror, January 20, 1878.

81. I use the term 'charismatic' in the Weberian sense. Weber defines charisma as 'a certain quality of an individual personality by virtue of which he is considered extraordinary and treated as endowed with supernatural, superhuman, or at least specifically exceptional powers or qualities. These are such as are not accessible to the ordinary person, but are regarded as of divine origin or as exemplary, and on the basis of them the individual concerned is treated as a "leader"'. Weber, Economy and Society, 241.

82. For missionary loyalty, see Damen, Crisis and Religious Renewal, 184.

83. Keshab writing in the "devotional" column of the Sunday Mirror, September 19, 1880, reprinted in Collet, The Brahmo Year Book (1880), 35-36.

\section{References}

Borthwick, M. Keshub Chunder Sen: A Search for Cultural Synthesis. Calcutta: Minerva, 1977.

Burton, A. "From Child Bride to "Hindoo Lady": Rukhmabai and the Debate on Sexual Respectability in Imperial Britain." The American Historical Review 103, no. 4 (1998): 1119-1146.

Carpenter, M. Six Months in India. 2 Vols. London: Longman, Green, 1868.

Chatterjee, I. Gender, Slavery and Law in Colonial India. Delhi: Oxford University 
This is the accepted version of the article accepted for publication in South Asian History and Culture published online by Taylor \& Francis on 23 Aug 2016, available at: http://dx.doi.org/10.1080/19472498.2016.1223720

Accepted version downloaded from SOAS Research Online: http://eprints.soas.ac.uk/22864/

Press,1999.

Chatterjee, P. The Nation and Its Fragments: Colonial and Postcolonial Histories.

Princeton: Princeton University Press, 1993.

Collet, S. D. ed. Keshub Chunder Sen's English Visit. London: Strahan and Co., 1871.

Collet, S. D. ed. The Brahmo Year Book. Brief Records of Work and Life in the Theistic

Churches of India. 7 vols. London, Edinburgh: Williams and Norgate, 1876-1883.

Damen, F. Crisis and Religious Renewal in the Brahmo Samaj (1860-1884): A

Documentary Study of the Emergence of the "New Dispensation" under Keshab

Chandra Sen. Belgium: Katholieke Universiteit Leuven, 1983.

Devee, S. The Autobiography of an Indian Princess. London: John Murray, 1921.

Ernst, W. and B. Pati, eds. India's Princely States: People, Princes and Colonialism.

London and New York: Routledge, 2007.

Ferguson, M. ed. The History of Mary Prince, A West Indian Slave, Related by Herself.

University of Michigan Press, 1987.

Forbes, G. H. "Women and Modernity: The Issue of Child Marriage in India." Women's Studies International Quarterly 2 (1979): 407-419.

Heimsath, C. H. "The Origin and Enactment of the Indian Age of Consent Bill, 1891."

Journal of Asian Studies 21, no. 4 (1962): 491-504.

Jhala, A. D. Courtly Indian Women in Late Imperial India. London: Pickering and Chatto, 2008.

Kapadia, K. M. Marriage and Family in India. Calcutta: Oxford University Press, 1966.

Koditschek, T. Liberalism, Imperialism, and the Historical Imagination: Nineteenth-

Century Visions of a Greater Britain. Cambridge University Press, 2011.

Kopf, D. The Brahmo Samaj and the Shaping of the Modern Indian Mind. New Jersey:

Princeton University Press, 1979.

Levine, P. Prostitution, Race and Politics: Policing Venereal Disease in the British

Empire. New York: Routledge, 2003.

Levine, P. "Venereal Disease, Prostitution and the Politics and Empire: The Case of British India." Journal of the History of Sexuality 4, no. 4 (1994): 579-602. 
This is the accepted version of the article accepted for publication in South Asian History and Culture published online by Taylor \& Francis on 23 Aug 2016, available at: http://dx.doi.org/10.1080/19472498.2016.1223720

Accepted version downloaded from SOAS Research Online: http://eprints.soas.ac.uk/22864/

Majumdar, R. Marriage and Modernity: Family Values in Colonial Bengal. Durham and London: Duke University Press, 2009.

Moore, L. Maharanis: The Lives and Times of Three Generations of Indian Princesses. Viking, 2004.

Mozoomdar, P. C. The Life and Teachings of Keshub Chunder Sen. 3rd ed. Calcutta: Nababidhan Trust, 1931.

Müller, M. Biographical Essays. London: Longmans Green \& Co., 1884.

Nair, J. Women and Law in Colonial India: A Social History. New Delhi: Kali for Women, 1996.

Paton, D. “Decency, Dependence and the Lash: Gender and the British Debate over Slave Emancipation, 1830-34," Slavery and Abolition 17, no. 3 (1996): 163-184.

Radice, W. "Tagore's The Religion of Man." Faith and Freedom 63, no. 2 (2010): 99116.

Ramusack, B. N. The Indian Princes and Their States. Cambridge University Press, 2004. Raychaudhuri, T. Europe Reconsidered: Perceptions of the West in Nineteenth-Century Bengal. New Delhi: Oxford University Press, 2002.

Sastri, S. History of the Brahmo Samaj. 2nd ed. Calcutta: Sadharan Brahmo Samaj, 1974.

Scherer, M. A. "A Cross-Cultural Conflict Reexamined: Annette Ackroyd and Keshub Chunder Sen." Journal of World History 7, no. 2 (1996): 231-259.

Sen, P. K. Biography of a New Faith: Volume Two. Calcutta: Thacker Spink \& Co., 1954. Sharafi, M. Law and Identity in Colonial South Asia: Parsi Legal Culture, 1772-1947. New York: Cambridge University Press, 2014.

Sturman, R. The Government of Social Life in Colonial India: Liberalism, Religious Law, and Women's Rights. Cambridge University Press, 2012.

Walkowitz, J. R. City of Dreadful Delight: Narratives of Sexual Danger in Late-Victorian London. University of Chicago Press, 1992.

Walkowitz, J. R., Prostitution and Victorian Society: Women, Class and the State. Cambridge, 1980. 
This is the accepted version of the article accepted for publication in South Asian History and Culture published online by Taylor \& Francis on 23 Aug 2016, available at: http://dx.doi.org/10.1080/19472498.2016.1223720

Accepted version downloaded from SOAS Research Online: http://eprints.soas.ac.uk/22864/

Weber, M. Economy and Society: An Outline of Interpretive Sociology, Volume One.

Berkeley, Los Angeles, London: University of California Press, 1978.

Writers Workshop. Keshub Chunder Sen in England: Diaries, Sermons, Addresses and

Epistles. Calcutta: Writers Workshop, 1980.

Writers Workshop. Sucharu Devi: Maharani of Mayurbhanj: A Biography. Calcutta:

Writers Workshop, 1979. 